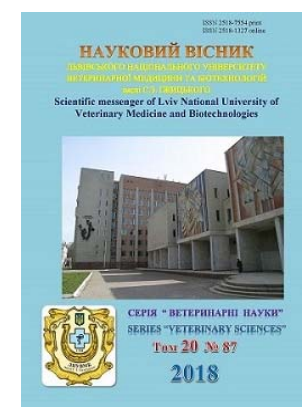

\author{
Науковий вісник Дьвівського національного університету \\ ветеринарної медицини та біотехнологій імені С.З. Гжицького
}

\author{
Scientific Messenger of Lviv National University \\ of Veterinary Medicine and Biotechnologies
}

\title{
Antibiotic resistance of lactis acid bacteria and the risk of its transmission with fermented dairy products
}

\author{
I.M. Slyvka, O.Y. Tsisaryk, L.Y. Musiy \\ Stepan Gzhytskyi National University of Veterinary Medicine and Biotechnologies Lviv, Ukraine
}

Article info

Received 15.02.2018

Received in revised form 23.03.2018

Accepted 26.03.2018

Stepan Gzhytskyi National University of Veterinary Medicine and Biotechnologies Lviv, Pekarska str., 50, Lviv. 79010, Ukraine.

Тел.: +38-067-600-11-04; +38-097-986-15-44; +38-098-132-31-63

E-mail: slyvka.88@ukr.net, tsisaryk_o@yaoo.com musiyluba@ukr.net
Slyvka, I.M., Tsisaryk, O.Y., \& Musiy, L.Y. (2018). Antibiotic resistance of lactis acid bacteria and the risk of its transmission with fermented dairy products. Scientific Messenger of Lviv National University of Veterinary Medicine and Biotechnologies. 20(87), 78-84. doi: 10.15421/nvlvet8716

Bacterial resistance to antimicrobials is a global health problem that affects not only on humane and veterinary medicine, but also on food products. The food chain can be by transmission of antibiotic resistance from bacterial populations to animals and humans. Literary data on the current state of the problem of antibiotic resistance of lactic acid bacteria (LAB) in Ukraine and in the world are given in the review. Possible ways of transferring resistance to antibiotics through fermented dairy products are shown. The main aspects of the danger of transmission of antibiotic resistance genes through the LAB and fermented dairy products are revealed. The main modern approaches to the definition of antibiotic resistance of microorganisms with the use of classical and modern research methods are described. The article provides the main sources of information on the safety of use of LAB as starter cultures and probiotics for the production of fermented dairy products. The hypothesis of the resistance gene's reservoir suggests that $L A B$ can be a reservoir of sustainability genes, and the subsequent transfer of such genes to pathogenic and opportunistic microorganisms. The presence of antibiotic resistance genes transposed horizontally is inadmissible for lactobacilli, which are used as commercial bacterial agents for the production of fermented dairy products. According to the literature data, the absence of acquired antimicrobial resistance has become an important criterion for assessing the safety of lactobacilli, which are used as starting cultures for the production of fermented dairy products or probiotics. It has been established that it is obligatory to study the antibiotic resistance gene in addition to clinical and laboratory methods of studying the antibiotic resistance of LAB. To minimize the formation of antibiotic-resistant bacteria in food products of plant and animal origin it is possible by careful monitoring of residues of antibiotics in raw materials and finished products. This will prevent the entry of antibiotic resistant strains into the natural cycle.

Key words: lactic acid bacteria, antibiotic resistance, probiotics, antibiotics, gene reservoir, fermented dairy products.

\section{Стійкість до антибіотиків молочнокислих бактерій і загроза її передачі 3 ферментованими молочними продуктами}

\author{
І.М. Сливка, О.Й. Цісарик, Л.Я. Мусій \\ Львівський національний університет ветеринарної медицини та біотехнологій імені С.3. Гжицького, \\ м. Львів, Україна
}

Бактеріальна стійкість до антимікробних препаратів - глобальна проблема охорони здоров'я, яка впливає не лише на гуманну і ветеринарну медицину, а й на виробництво харчових продуктів, оскільки харчовий ланцюг стає можливим иляхом поширення антибіотичного опору серед бактеріальних популячій тварин і людей. В огляді наведено літературні дані щодо сучасного стану проблеми антибіотикорезистентності молочнокислих бактерій (МКБ) в Украӥні та світі. Охорактеризовано можливі иляхи передачі стійкості до антибіотиків через ферментовані молочні продукти. Розкрито основні аспекти небезпеки поширення генів антибіотикорезистентності через МКБ та ферментовані молочні продукти. Описано основні сучасні підходи до визначення антибіотикорезистентності мікроорганізмів із застосуванням класичних $і$ сучасних методів дослідження. У роботі наведено основні джерела інформації з питань безпеки використання МКБ в ролі стартових культур і пробіотиків для виробництва ферме- 
нтованих молочних продуктів. Гіпотеза резервуару генів резистентності припускає, щзо МКБ можуть бути резервуаром генів стійкості з подальшим перенесенням таких генів до патогенних та опортуністичних мікроорганізмів. Наявність генів антибіотикорезистентності, які перенесені горизонтальним шляхом є недопустимим для лактобактерій, які використовуються як комериійні бактеріальні препарати для виробництва ферментованих молочних продуктів. Згідно з літературними даними встановлено, ше відсутність набутої антимікробної стійкості стала важливим критерієм для оцінки безпеки лактобактерій, які використовуються, як стартові культури для виробництва ферментованих молочних продуктів або пробіотики. Встановлено, ичо крім клінічних та лабораторних методів дослідження антибіотикорезистентності МКБ, обов'язковим є вивчення гена антибіотикорезистентності. Мінімізувати утворення резистентних до антибіотиків бактерій у продуктах рослинного та тваринного походження, можна шляхом ретельного моніторингу залишків антибіотиків у сировині та готових продуктах. Це дозволить уникнути потрапляння антибіотикорезистентних итамів у природний кругообіг.

Ключові слова: молочнокислі бактерії, антибіотикорезистентність, пробіотики, антибіотики, резервуар генів, ферментовані молочні продукти.

Молочнокислі бактерії (МКБ) традиційно використовуються як компоненти заквасок для харчових продуктів. Крім того, вони є нормофлорою шлунковокишкового тракту людини, а деякі штами активно використовуються у ролі пробіотиків.

Пробіотики - це живі мікроорганізми або їх метаболіти, які можуть позитивно впливати на здоров'я людини, нормалізувати мікробний баланс кишківника, що призводить до поліпшення стану здоров'я (Sánchez et al., 2017).

Багато різновидів лактобактерій, які використовуються в ролі пробіотиків, попередньо визнаних як безпечні - Generally Regarded As Safe (GRAS) (Monahan, 2011), можливо, стають векторами передачі генів антибіотичної резистентності. Ці бактерії, зазвичай, споживаються у великих кількостях, і контакт з іншими бактеріями у гастроінтенстинальному тракті людини забезпечує досконалі умови для горизонтальної передачі кон'югативних плазмід і транспозони 3 генами, що кодують опір до антимікробних агентів (Mathur and Singh 2005; Jacobsen et al., 2007; Ammor et al., 2008; Nawaz et al., 2011). Відсутність набутої антимікробної стійкості стала важливим критерієм для оцінки безпеки лактобактерій, які використовуються як стартові культури для виробництва ферментованих молочних продуктів або пробіотики (Mayrhofer et al., 2008).

Продовольча та сільськогосподарська організація Організації Об'єднаних Націй та Всесвітньої Організації Здоров'я розробила керівні принципи для оцінки безпеки пробіотиків. Пробіотики, які використовуються комерційно в харчовій промисловості, повинні бути досліджені на антибіотикорезистентність (FАОWHO, 2002).

В усьому світі спостерігається загострення проблеми щодо антимікробної резистентності мікроорганізмів, що становить загрозу здоров'ю людей та тварин. Тепер існує відносно небагато стандартних методів для оцінки резистентності до антибіотиків пробіотичних мікроорганізмів. Стандарти для вивчення антибіотикорезистентності МКБ передбачають клінічні та лабораторні методи дослідження, але не вивчення гена антибіотикорезистентності (CLSI, 2006).

Більшість бактерій є носіями генів, які відповідають за різні механізми стійкості до антибіотичних препаратів. Сукупність генів, що кодують стійкість до антимікробних препаратів, нещодавно назвали резистомою («resistome»). До недавнього часу при дослідженні резистентності мікроорганізмів використовували ізоляти патогенних бактеріальних штамів. Од- нак, на думку ряду авторів, бактерії гастроінтенстинальної мікробіоти (молочнокислі бактерії і біфідобактерії) можуть бути резервуаром генів антибіотикорезистентності, які можуть передаватися через гастроінтестинальний тракт людини патогенним бактеріальним штамам, що викликають різні інфекційні захворювання. Сучасні дослідження біологічної безпеки лактобактерій, повинні включати не тільки визначення наявності ознак стійкості до антибіотиків, а й дослідження мікроорганізмів на наявність генів антибіотикорезистентності і виявлення можливості передачі лікарської резистентності. Вивчення поширення генів антибіотикорезистентності у МКБ допоможе кращому розумінню їх ролі в передачі ознак антибіотикорезистентності і вирішенні проблеми біологічної безпеки заквашувальних і пробіотичних мікроорганізмів (Botina, 2008).

Сьогодні стратегією для лікувальних цілей є можливість використання комбінацій пробіотиків та антибіотиків (Govender et al., 2016), але це питання залишається суперечливим. Використання пробіотиків 3 низьким рівнем опору може бути неефективним у поєднанні 3 антибіотиками, якщо вони гальмуються антибіотиками, тоді як пробіотики 3 високим ступенем резистентності можуть створювати проблему через можливість передачі генів антибіотикорезистентності від пробіотика до патогенного мікроорганізмy.

Механізми антибіотикорезистентності різні: у деяких випадках мікроорганізми змінюють свою будову, в інших - починають виробляти речовини, що зв'язують антибіотики. Хвороби, що викликаються антибіотикорезистентними мікробами, протікають важче і гірше піддаються лікуванню. Взагалі, у лікуванні таких хвороб можуть бути використані тільки нові та сильні антибіотики або синтетичні препарати, які ще не відомі мікробам (Fedorenko, 2001).

Отже, ефективність поширення резистентності до антибіотиків визначається, як мінімум, двома головними факторами: наявністю генів резистентності та селективним тиском, які створюють антибіотики.

Безконтрольне і нераціональне використання антибіотиків як лікувальних та стимулюючих засобів, призвело до того, що продукти тваринного походження, в тому числі молоко, нерідко містять залишкові кількості цих препаратів. Розчини антибіотиків вводять безпосередньо в уражені частки молочної залози при маститах (Butsenko et al., 2010).

Пастеризація молока сприяє руйнуванню лише $6 . .28 \%$ антибіотиків, що містяться в ньому. Антибіо- 
тики погіршують результати редуктазної проби, завищуючи класність молока за бактеріальним забрудненням. Наявність у молоці антибіотиків пригнічує розвиток МКБ, що застосовуються при виробництві кисломолочних та інших молочних продуктів (Butsenko et al., 2010). Крім того, вони порушують сичужне зсідання молока при виробництві сиру, що негативно позначається на смакових якостях і консистенції цієї продукції (Langford et al., 2003; Borovkov et al., 2010).

Відповідно до діючих стандартів (EFSA, 2012), пробіотики у харчових продуктах повинні бути чутливими до антибіотиків.

МКБ, які використовуються в ролі пробіотиків, можуть мати природну стійкість до антибіотиків, як наприклад: у Leuconostoc та деяких лактобактерій до ванкоміцину чи налідиксової кислоти. Природна резистентність не передається горизонтально, тому такі бактерії не становлять загрози. На відміну від природної, набута резистентність з'являється у деяких штамів певного виду, що, зазвичай, є чутливим до антибіотика. $€$ дані, що гени стійкості до антибіотиків, які містяться у МКБ, можуть передаватися до патогенних бактерій у процесі виробництва харчових продуктів або під час проходження їх через шлунковий тракт людини. Немає жодного бар'єру між патогенними мікроорганізмами (стрептококами), потенційно патогенними (ентерококами) та коменсалами (лактобацилами кишківника, лактококами), який би запобігав передачі набутої резистентності. Ідентичні за нуклеотидною послідовністю гени стійкості до тетрацикліну, еритроміцину, хлорамфеніколу, стрептоміцину, та стрептограміну були знайдені у всіх трьох групах бактерій (Mathur and Singh, 2005).

Значна частина пробіотиків чутлива до більшості антибіотиків. Дані літератури (Bergogne-Berezin, 1995) свідчать про те, що Lactobacilli, Enterococci, Bacillus cereus i Bifidobacteria не є резистентними до таких широкого застосовуваних антибіотиків, як амоксицилін, доксициклін, фторхінолони і цефалоспорини. Це суттєвий недолік бактерійних препаратів, що дуже обмежує їх використання, адже їх поєднання 3 антибіотикотерапією або застосування безпосередньо після неї неминуче супроводжується інактивацією штамів таких пробіотиків. Тому було запропоновано використовувати антибіотикорезистентні штами мікроорганізмів. Полірезистентні пробіотики можуть застосовуватися одночасно з антибіотиками для профілактики виникнення побічних явищ з боку травного каналу, спричинених пероральними антибіотиками.

Проте такий підхід має ряд недоліків. Передусім у такому випадку існує ризик плазмідної передачі патогенам резистентності до антибіотиків (Elmer, 1999). Було продемонстроване перенесення плазмід iз Lactobacillus reuteri на Enterococcus faecium, а також 3 E. faecium на $E$. faecalis у процесі приготування м'ясної і молочної продукції (Gevers, 2003). Інфікування E. faecium становить серйозну небезпеку тому, що у багатьох штамів цієї бактерії $є$ плазміди, які кодують резистентність до різноманітних антибіотиків, включаючи ванкоміцин (Elmer, 1999). Ці знахідки насторожують і вимагають контролю за культурами МКБ, які використовуються для виробництва харчових продуктів, на відсутність мобільних генетичних елементів, які включають гени антибіотикорезистентності.

Через небезпеку існування резистентності ентерококів до ванкоміцину, що може передаватися іншим мультирезистентним бактеріям, використання цього антибіотика рекомендується обмежити (Murray, 1995; CDC, 1995). У Бельгії в 1994 р. був скандально вилучений з продажу пробіотик, до складу якого входив ентерокок (E. faecium SF 68).

Поряд 3 набутою існує ще й принципово інший тип бактерійної антибіотикорезистентності - істинна (природна або первинна). Істинна резистентність притаманна всім штамам конкретного роду або виду; вона обмежує спектр бактерійної активності певного антибіотика. Ця резистентність $є$ хромосомноопосередкованою і за жодних обставин не передається іншим бактеріям (Courvalin, 2001).

Таким чином, пошук мікроорганізмів, які можна використовувати як пробіотики, є тривалим і складним процесом.

Потенційним джерелом пошуку нових штамів МКБ, перспективних для використання в складі бактеріальних і пробіотичних препаратів, $є$ вітчизняні кисломолочні продукти та сири, мікрофлора яких в Україні не вивчена (Chaharovskyу, 2003; Kihel, 2003; Bondarenko et al., 2004). Дослідження мікрофлори традиційних національних молочних продуктів може слугувати не тільки збереженню природних біоценозів, які формувалися упродовж століть в конкретних умовах, але й створенню бактеріальних препаратів для промислового використання.

Авторами (Slyvka and Tsisaryk, 2013; Slyvka and Tsisaryk, 2015) ідентифіковано на генетичномолекулярному рівні та вивчено властивості, в тому числі антибіотикорезистентність, семи штамів МКБ, виділених із традиційного карпатського сиру - бринза.

Бринза як традиційний український продукт є абсолютно невивченим мікробіологічним об'єктом, а в останні роки до традиційних національних продуктів прикута особлива увага науковців. Створення «регіональних» заквасок на основі штамів, які виділяють із природних еконіш $є$ перспективним, адже «місцеві» штами краще пристосовані до еколого-географічних умов конкретної кліматичної зони.

Результати дослідження антибіотикорезистентності штамів МКБ, виділених із традиційної карпатської бринзи наведені в таблицях 1 і 2 .

Із карпатської бринзи нами виділено чотири штами бактерій роду Enterococcus, які не внесені за нуклеотидною послідовністю до бази Nucleotid Seqence Database of National Center for Biotecnology Information (Gen Bank NCBI). Штами отримали номери SB 6, SB 12, SB 18, SB 20. Результати визначення чутливості досліджуваних штамів ентерококів до антибіотиків наведено у таблиці 2. Виділені культури кваліфікували як нечутливі, помірно чутливі та чутливі - за величиною зон затримки росту. 
Таблиця 1

Антибіотикорезистентність штамів молочнокислих бактерій виділених із традиційної карпатської бринзи, $\mathrm{M} \pm \mathrm{m}, \mathrm{n}=3$

\begin{tabular}{|c|c|c|c|c|c|c|c|c|}
\hline \multirow[b]{2}{*}{$\begin{array}{c}\text { Диски } 3 \\
\text { антибіотиками }\end{array}$} & \multirow[b]{2}{*}{$\begin{array}{c}\text { Конце- } \\
\text { нтра- } \\
\text { ція, мкг }\end{array}$} & \multicolumn{7}{|c|}{ Зони затримки росту (мм) } \\
\hline & & $\begin{array}{l}\text { Lactobacillus } \\
\text { plantarum } \\
\text { strain } \\
\text { RU26303 }\end{array}$ & $\begin{array}{c}\text { Lactococcus } \\
\text { lactis } \\
\text { subsp.lactis } \\
\text { strain } \\
\text { IMAU32258 }\end{array}$ & $\begin{array}{c}\text { Lactobacillus } \\
\text { plantarum } \\
\text { strain } \\
\text { WCFS1 }\end{array}$ & $\begin{array}{l}\text { Lactobacillus } \\
\text { plantarum } \\
\text { strain } \\
\text { KLDS } 1.0728\end{array}$ & $\begin{array}{c}\text { Leuconostoc } \\
\text { mesenteroides } \\
\text { strain } \\
\text { SWU99202 }\end{array}$ & $\begin{array}{c}\text { Leuconostoc } \\
\text { mesenteroides } \\
\text { strain } \\
\text { A7 }\end{array}$ & $\begin{array}{c}\text { Lactobacillus } \\
\text { plantarum } \\
\text { strain } \\
\text { C11(5) }\end{array}$ \\
\hline Амоксицилін & 10 & $20,3 \pm 0,3$ & $21,7 \pm 0,2$ & $19,7 \pm 0,1$ & $22,7 \pm 0,5$ & $21,3 \pm 0,5$ & $20,7 \pm 0,3$ & $23,7 \pm 0,3$ \\
\hline Оксацилін & 5 & $9,3 \pm 0,2$ & - & $10,3 \pm 0,1$ & $12,3 \pm 0,3$ & $11,7 \pm 0,2$ & $9,7 \pm 0,1$ & $10,0 \pm 0,3$ \\
\hline Гентаміцин & 10 & $24,3 \pm 0,3$ & $23,3 \pm 0,3$ & $21,0 \pm 0,6$ & $25,7 \pm 0,3$ & $27,7 \pm 0,5$ & $21,3 \pm 0,6$ & $23,7 \pm 0,3$ \\
\hline Стрептоміцин & 10 & $13,3 \pm 0,3$ & $11,7 \pm 0,3$ & $9,7 \pm 0,1$ & $10,3 \pm 0,3$ & $10,7 \pm 0,1$ & $11,3 \pm 0,3$ & $12,7 \pm 0,3$ \\
\hline Канаміцин & 30 & $13,7 \pm 0,3$ & $12,7 \pm 0,1$ & $16,3 \pm 0,3$ & $10,3 \pm 0,3$ & $17,7 \pm 0,3$ & $15,0 \pm 0,3$ & $18,3 \pm 0,3$ \\
\hline Еритроміцин & 10 & $31,7 \pm 0,3$ & $28,3 \pm 0,3$ & $21,7 \pm 0,3$ & $23,3 \pm 0,3$ & $26,3 \pm 0,6$ & $25,7 \pm 0,3$ & $32,3 \pm 0,3$ \\
\hline Тилозин & 15 & $23,3 \pm 0,3$ & $29,3 \pm 0,3$ & $18,3 \pm 0,2$ & $20,6 \pm 0,3$ & $22,7 \pm 0,3$ & $27,7 \pm 0,3$ & $31,7 \pm 0,3$ \\
\hline Тетрациклін & 10 & $24,3 \pm 0,3$ & $25,7 \pm 0,1$ & $25,0 \pm 0,3$ & $29,3 \pm 0,3$ & $24,3 \pm 0,3$ & $26,3 \pm 0,3$ & $25,0 \pm 0,3$ \\
\hline $\begin{array}{l}\text { Доксицикліну } \\
\text { гідрохлорид }\end{array}$ & 10 & $24,7 \pm 0,5$ & $25,3 \pm 0,03$ & $23,7 \pm 0,3$ & $31,6 \pm 0,3$ & $29,0 \pm 0,3$ & $25,7 \pm 0,3$ & $24,7 \pm 0,3$ \\
\hline $\begin{array}{l}\text { Ципрофлокса- } \\
\text { цин }\end{array}$ & 15 & - & - & $14,7 \pm 0,3$ & $15,6 \pm 0,3$ & $12,7 \pm 0,3$ & - & $10,0 \pm 0,3$ \\
\hline Норфлоксацин & 10 & $10,0 \pm 0,1$ & - & $14,7 \pm 0,1$ & $19,0 \pm 0,3$ & $17,7 \pm 0,3$ & $19,3 \pm 0,3$ & $9,7 \pm 0,3$ \\
\hline Цефалексин & 30 & $16,3 \pm 0,3$ & $14,3 \pm 0,3$ & $15,3 \pm 0,1$ & $19,3 \pm 0,3$ & $15,0 \pm 0,3$ & $16,7 \pm 0,3$ & $18,3 \pm 0,3$ \\
\hline Цефазолін & 30 & $19,3 \pm 0,3$ & $14,3 \pm 0,3$ & $18,3 \pm 0,3$ & $24,3 \pm 0,3$ & $21,3 \pm 0,3$ & $20,3 \pm 0,3$ & $21,7 \pm 0,3$ \\
\hline Нітрофуратоїн & 300 & $25,3 \pm 0,3$ & $26,3 \pm 0,3$ & $15,3 \pm 0,6$ & $15,3 \pm 0,3$ & $22,3 \pm 0,3$ & $22,7 \pm 0,3$ & $27,3 \pm 0,3$ \\
\hline Левоміцетин & 30 & $27,3 \pm 0,3$ & $26,3 \pm 0,3$ & $20,7 \pm 0,3$ & $25,6 \pm 03$ & $24,7 \pm 0,3$ & $24,0 \pm 0,3$ & $28,3 \pm 0,3$ \\
\hline Ванкоміцин & 30 & - & - & $16,7 \pm 0,3$ & $20,6 \pm 0,1$ & $19,3 \pm 0,3$ & $16,3 \pm 0,3$ & - \\
\hline Поліміксин В & 100 & $11,7 \pm 0,3$ & $12,0 \pm 0,3$ & - & - & $14,7 \pm 0,3$ & $10,7 \pm 0,3$ & $12,3 \pm 0,3$ \\
\hline Рифампіцин & 15 & $25,7 \pm 0,3$ & $25,7 \pm 0,6$ & $9,7 \pm 0,1$ & $29,6 \pm 0,3$ & $25,0 \pm 0,3$ & $21,0 \pm 0,3$ & $24,7 \pm 0,3$ \\
\hline
\end{tabular}

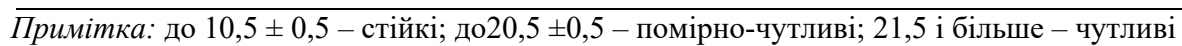

За результатами проведених досліджень встановлено, що досліджувані штами МКБ, виділені із традиційної карпатської бринзи продемонстрували високу чутливість до антибіотиків усіх груп, за винятком аміноглікозидів (стрептоміцин, канаміцин) та пеніцилінів. Природна чутливість до аміноглікозидів пояснюється тим, що у анаеробів, відсутні системи перенесення цих антибіотиків через плазматичну мембрану клітини (Botina, 2008).

Стійкість до пеніцилінів можна обгрунтувати наявністю в МКБ спеціальних ферментів, які інактивують дію пеніциліну. Такі ферменти мають назву бета лактамази або пеніцилініази - група бактеріальних ферментів, здатних розривати бета-лактамне кільце деяких антибіотиків (пеніцилінів, цефалоспоринів, карбапенемів та монобактамів), що відносяться до класу беталактамів (Busani et al., 2004).

Варто зазначити, що стійкість до антибіотиків у промислових мікроорганізмів сама собою не є негати- вним фактором, але при застосуванні таких культур у ферментованих продуктах можливе перенесення генів антибіотикорезистентності до мікрофлори хазяїна, що небажано. Серед досліджуваних штамів МКБ більшість виявилися чутливими до широкого спектру антимікробних препаратів, такі штами надалі можуть бути використані як стартові культури у складі бактеріальних препаратів.

Таким чином, для біотехнологів, мікробіологів, спеціалістів, які працюють з харчовими продуктами, $є$ очевидним фактом, що необхідно уникати поширення бактерій, що несуть мобільні гени стійкості. Тому бактеріальні штами, які застосовують для виготовлення пробіотиків або заквашувальних культур для виробництва кормів та продуктів харчування, повинні бути перевірені на стійкість до антибіотиків для запобігання небажаного перенесення резистентності чи набуття стійкості бактеріями макроорганізму. 
Таблиця 2

Антибіотикорезистентність штамів Enterococcus виділених із традиційної карпатської бринзи, $\mathrm{M} \pm \mathrm{m}, \mathrm{n}=3$

\begin{tabular}{lccccc}
\hline \multicolumn{1}{c}{ Диски з антибіотиками } & Концентрація, & \multicolumn{3}{c}{ Зони затримки росту (мм) } \\
\cline { 3 - 6 } мкг & SB 20 & SB 18 & SB 6 & SB 12 \\
\hline Амоксицилін & 10 & $25,6 \pm 0,3$ & $30,3 \pm 0,3$ & $26,0 \pm 0,1$ & $25,0 \pm 0,5$ \\
Оксацилін & 5 & $22,3 \pm 0,6$ & $22,3 \pm 0,3$ & $21,3 \pm 0,3$ & $19,6 \pm 0,3$ \\
Гентаміцин & 10 & $15,3 \pm 0,3$ & $16,0 \pm 0,3$ & $13,6 \pm 0,3$ & $14,6 \pm 0,3$ \\
Стрептоміцин & 10 & - & $9,6 \pm 0,3$ & - & $10,3 \pm 0,3$ \\
Канаміцин & 30 & $9,6 \pm 0,3$ & $11,6 \pm 0,3$ & $10,3 \pm 0,3$ & $10,3 \pm 0,3$ \\
Еритроміцин & 10 & $21,3 \pm 0,3$ & $23,6 \pm 0,3$ & $25,6 \pm 0,3$ & $23,3 \pm 0,3$ \\
Тилозин & 15 & $24,6 \pm 0,3$ & $24,3 \pm 0,3$ & $29,3 \pm 0,3$ & $20,6 \pm 0,3$ \\
Тетрациклін & 10 & $31,6 \pm 0,3$ & $32,0 \pm 0,1$ & $31,6 \pm 0,3$ & $29,3 \pm 0,3$ \\
Доксицикліну гідрохлорид & 10 & $30,0 \pm 0,5$ & $31,6 \pm 0,03$ & $30,3 \pm 0,3$ & $31,6 \pm 0,3$ \\
Ципрофлоксацин & 15 & $18,6 \pm 0,3$ & $16,6 \pm 0,3$ & $14,3 \pm 0,3$ & $15,6 \pm 0,3$ \\
Норфлоксаци & 10 & $18,6 \pm 0,3$ & $17,6 \pm 0,3$ & $19,3 \pm 0,3$ & $19,0 \pm 0,3$ \\
Цефалексин & 30 & $21,3 \pm 0,3$ & $19,6 \pm 0,3$ & $21,0 \pm 0,3$ & $19,3 \pm 0,3$ \\
Цефазолін & 30 & $28,3 \pm 0,3$ & $28,3 \pm 0,3$ & $26,6 \pm 0,3$ & $24,3 \pm 0,3$ \\
Нітрофуратоїн & 300 & $18,3 \pm 0,3$ & $18,0 \pm 0,3$ & $17,6 \pm 0,6$ & $15,3 \pm 0,3$ \\
Левоміцетин & 30 & $23,6 \pm 0,3$ & $25,0 \pm 0,3$ & $24,6 \pm 0,3$ & $25,6 \pm 03$ \\
Ванкоміцин & 30 & $20,3 \pm 0,3$ & $21,3 \pm 0,3$ & $20,6 \pm 0,3$ & $20,6 \pm 0,3$ \\
Поліміксин В & 100 & - & - & - & - \\
Рифампіцин & 15 & $31,3 \pm 0,3$ & $32,3 \pm 0,3$ & $30,6 \pm 0,3$ & $29,6 \pm 0,3$ \\
\hline
\end{tabular}

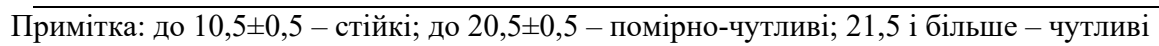

\section{Висновки}

Основним критерієм оцінки безпеки штамів МКБ, які використовуються або перспективні для використання в ролі стартових або пробіотичних культур, $є$ чутливість до клінічно важливих антибіотиків.

Гіпотеза резервуару генів резистентності допускає, що бактерії-коменсали (до яких відносять і МКБ) можуть бути резервуаром генів стійкості з подальшим перенесенням таких генів до патогенних та опортуністичних мікроорганізмів.

Наявність генів антибіотикорезистентності, які перенесені горизонтальним шляхом, $\epsilon$ недопустимим для лактобактерій, які використовуються як комерційні бактеріальні препарати для виробництва ферментованих молочних продуктів.

Крім клінічних та лабораторних методів дослідження антибіотикорезистентності молочнокислих бактерій, обов'язковим є вивчення гена антибіотикорезистентності.

Мінімізувати утворення резистентних до антибіотиків бактерій у продуктах рослинного та тваринного походження можна шляхом ретельного моніторингу залишків антибіотиків у сировині та готових продуктах. Це дозволить уникнути потрапляння антибіотикорезистентних штамів у природний кругообіг.

Дослідження виконанні за рахунок коштів наукового проекту «Біотехнологія створення вітчизняних бактеріальних препаратів для молочної промисловості» (0116U20853).

\section{References}

Ammor, M.S., Flórez, A.B., van Hoek, A.H.A.M., de los Reyes-Gavilán, C.G., Aarts, H.J.M., Margolles, A., \& Mayo, B. (2008). Molecular characterization of intrinsic and acquired antibiotic resistance in lactic acid bacteria and bifidobacteria. Journal of Molecular Microbiology and Biotechnology. 14, 6-15. doi: 10.1159/000106077.

Mathur, S., \& Singh, R. (2005). Antibiotic resistance in food lactic acid bacteria - a review. International Journal of Food Microbiology. 105(3), 281-295. doi: 10.1016/j.ijfoodmicro.2005.03.008.

Jacobsen, L., Wilcks, A., Hammer, K., Huys, G., Gevers, D., \& Andersen, S.R. (2007). Horizontal transfer of tet(M) and erm(B) resistance plasmids from food strains of Lactobacillus plantarum to Enterococcus faecalis $\mathrm{JH} 2-2$ in the gastrointestinal tract of gnotobiotic rats. FEMS Microbiology Ecology. 59(1), 158-166. doi: 10.1111/j.1574-6941.2006.00212.x.

Nawaz, M., Wang, J., Zhou, A., Ma, C., Wu, X., Moore, J.E., Millar B.C., \& Xu, J. (2011). Characterization and transfer of antibiotic resistance in lactic acid bacteria from fermented food products. Current Microbiology. 62(3), 1081-1089. doi: 10.1007/s00284-010-9856-2. 
Mayrhofer, S., Domig, K.J., Mair, C., Zitz, U., Huys, G., \& Kneifel, W. (2008). Comparison of broth microdilution, Etest, and agar disk diffusion methods for antimicrobial susceptibility testing of Lactobacillus acidophilus group members. Applied and Environmental Microbiology. 74(12), 3745-3748. doi: 10.1128/AEM.02849-07.

FAO-WHO. (2002). Joint FAO/WHO working group report on drafting guidelines for the evaluation of probiotics in food. Food and Agricultural Organization of the United Nations, Rome, Italy, and World Health Organization, Geneva, Switzerland.

Monahan, J.C. (2011). The FDA and generally recognized as safe (GRAS) substances. Nova Science Publishers, Hauppauge, NY.

Sanchez, B., Delgado, S., Blanco-Mrguez, A., Lourenzo, A., Gueimonde, M., \& Margolles, A. (2017). Probiotics, gut microbiota, and their influence on host health and disease. Molecular Nutrition \& Food Research. 61(1). doi: 10.1002/ mnfr .201600240.

Lukačišinov, M., \& Bollenbach, T. (2017). Toward a quantitative understanding of antibiotic resistance evolution. Curr. Opin. Biotechnol. 46, 90-97. doi: 10.1016/j.copbio.2017.02.013.

CLSI. (2006). Methods for antimicrobial dilution and disk susceptibility testing of infrequently isolated or fastidious bacteria; proposed guideline. M45-P. 25th ed. Clinical and Laboratory Standards Institute, Wayne, PA.

Botina, S.H. (2008). Vidovaja identifikacija i pasportizacija molochnokislyh bakterij metodami molekuljarno-geneticheskogo tipirovanija. Molochnaja promyshlennost'. 3, 52-54 (in Russian).

Govender, M., Choonara, Y.E., van Vuuren, S., Kumar, P., Du, Toit, L.C., Erlwanger, K., \& Pillay, V. (2016). A dual-biotic system for the concurrent delivery of antibiotics and probiotics: in vitro, ex vivo, in vivo and in silico evaluation and correlation. Pharm. Res. 33(12), 3057-3071. doi: 10.1007/s11095-016-2030-1.

European Food Safety Authority (EFSA). (2012). Guidance on the assessment of bacterial susceptibility to antimicrobials of human and veterinary importance. EFSA J. 10:2740.

Butsenko, I.M., Penchuk, Yu.M., \& Pyroh, T.P. (2010). Tekhnolohii mikrobnoho syntezu likarskykh zasobiv. Navch. posib., NUKhT (in Ukrainian).

Borovkov, M.F., Frolov, V.P., \& Serko, S.A. (2010). Veterynarno-sanytarnaia эkspertyza s osnovamy tekhnolohyy y standartyzatsyy produktov zhyvotnovodstva. Uchebnyk pod red. prof. M.F. Borovkova. 3-e yzd., dop. y pererab. Sankt-Peterburh, Lan (in Russian).

Langford, F.M., Weary, D.M., \& Fisher, L. (2003). Antibiotic Resistance in Gut Bacteria from Dairy Calves: A Dose Response to the Level of Antibiotics Fed in Milk. Journal of Dairy Science. 86(12), 3963 3966. doi: 10.3168/jds.S0022-0302(03)74006-5

Fedorenko, V.O., Basiliia, L.I., Zavorotna, S.A., Holets, L.M., \& Kyrychenko, N.V. (2001). Henetychnyi kontrol biosyntezu antybiotykiv ta stiikosti do antybiotykiv $\mathrm{u}$ aktynomitsetiv. K.: Lohos (in Ukrainian).
Chaharovskyy, V.P., \& Zholkevskaya, Y.H. (2003). Byotekhnolohyya poluchenyya byoyohurtov y byokefyra, yzuchenye ykh vlyyanyya na zdorov'e cheloveka. Mikrobiolohichnyy zhurnal. 65(6), 67-73 (in Ukrainian).

Slyvka, I.M., \& Tsisaryk, O.J. (2013). Vydilennya molochnokyslyx bakterij iz ovechogo syru, vygotovlenogo $\mathrm{v}$ Bukovyns komu regioni ta yix identyfikaciya. Naukovyj visnyk LNUVM ta BT imeni S.Z. Gzhycz kogo. 15, 4(57), 116-121 (in Ukrainian).

Slyvka, I.M., \& Tsisaryk, O.J. (2015). Identyfikaciya molochnokyslyx bakterij iz zastosuvannyam kompleksu molekulyarno-genetychnyx metodiv. Naukovyj visnyk LNUVM ta BT imeni S.Z. Gzhyczkogo. 17, 1(61), 213-222 (in Ukrainian).

Busani, L., Del Grosso, M., Paladini, C., \& Gtazians, C. (2004). Antimicrobial susceptibility of vancomycinsusceptible and -resistant enterococci isolated in Italy from raw meat products, farm animals, and human infections. IInternational Journal of Food Microbiology. 97(1), 17-22. doi: 10.1016/j.ijfoodmicro.2004.04.008.

Kihel, N.F. (2003). Tekhnolohii bakterialnykh preparativ dlia funktsionalnykh produktiv i biolohichno aktyvnykh dobavok. Avtoreferat dysertatsii na zdobuttia naukovoho stupenia doktora tekhnichnykh nauk, Kyiv (in Ukrainian).

Slyvka, I.M. (2015). Biotehnologija stvorennja bakterial'nogo preparatu dlja vyrobnyctva brynzy. Dysertacija na zdobuttja naukovogo stupenja kandydata sil's'kogospodars'kyh nauk, Bila Cerkva (in Ukrainian).

Slyvka, I.M., \& Cisaryk, O.J. (2015). Deklaracijnyj patent Ukrai'ny na korysnu model' № u 201501858 . Konsorcium mikroorganizmiv Lactobacillus plantarum, Leuconostoc mesenteroides ssp. mesenteroides, Lactococcus lactis ssp. lactis, Lactococcus garvieae, Enterococcus faecium dlja vyrobnyctva syru brynza: zajavnyk i vlasnyk patentu L'vivs'kyj nacional'nyj universytet veterynarnoi' medycyny ta biotehnologij imeni S.Z Gzhyc'kogo. Zajavl. 02.03.2015 r., pozytyvne rishennja 03.06.2015 (in Ukrainian).

Tsisaryk, O., Slyvka, I., \& Musiy, L. (2017). Screening of technological properties of natural strains of lactic acid bacteria. Scientific Messenger LNUVMB. 19(80), 8892. doi: 10.15421/nvlvet8018.

Bondarenko, V.M. (2004). Probiotiki i mehanizmy ih lechebnogo. Jeksperim. klin. gastroenterol. 3, 83-87 (in Ukrainian)

Bergogne-Berezin, E. (1995). Impact ecologique de l'antibiotherapie. Place des microorganismes de substitution dansle controle des diarrhees et colites associees aux antibiotiques. 24, 145-156.

Elmer, G.W., Mc Farland, L.W., \& Surawicz, C.M. (1999). Biotherapeutic agents and infection diseases. New York: Human Press.

Gevers, D., Huys, G., \& Swings, J. (2003). In vitro conjugal transfer tetracycline resistance from Lactobacillus isolates to other Gram-positive bacteria. FEMS Microbiology Letters. 225(1), 125-130. doi: 10.1016/S0378-1097(03)00505-6. 
Centers for Disease Control. (1995). CDC issues recommendation for preventing spread of vancomycin resistance. Am. J. Health. Pharm. 52, 1272-1274.

Murray, B.E. (1995). Editorial responce: What can we do about vancomycin resistant enterococci? Clinical Infectious https://www.jstor.org/stable/4458518?seq=1\#page_sca $\mathrm{n}$ tab contents.

Courvalin, P., \& Trieu Cuot, P. (2001). Minimizing potential resistance: Molecular view. Clinical Infectious Diseases. 33, 138-146. doi: $10.1086 / 321840$. 